\title{
29. LOWER CRETACEOUS OSTRACODES FROM HOLE 537 (GULF OF MEXICO), LEG $77^{1}$
}

\author{
Henri J. Oertli, Elf Aquitaine, Centre Micoulau, 64018 Pau, France
}

\begin{abstract}
Three samples from Hole 537, Core 11, yielded seven species of ostracodes. Their state of preservation is too poor for specific determination. Nevertheless, approximate comparisons suggest that these samples are Neocomian; the environment was probably inner-neritic shallow-water (predominance of Asciocythere).
\end{abstract}

\section{INTRODUCTION}

Three washed and partially picked samples from Core 537-11, kindly provided by Isabella Premoli Silva, form the basis for this report. All three samples are from Section 11-1, two from between 0 and $10 \mathrm{~cm}$, the third at $134-137 \mathrm{~cm}$. They show no significant differences in their specific associations, but the frequency seems to be highest in the first sample $(0-4 \mathrm{~cm})$, from which a washing residue of about $2 \mathrm{~cm}$ of white silty marl yielded 86 specimens (exclusively single-valved). That molts and adults occur together, but always as single valves, suggests an undisturbed environment and a relatively slow sedimentation rate.

Most specimens are poorly preserved; the surface appears porous, and the interior and parts of the exterior are encrusted with sediment and crystals, often of considerable size. These crystals were proved by X-ray microanalysis to be calcite (see Fig. 1).

\section{SPECIES}

Little information exists to date on marine uppermost Jurassic to Lower Cretaceous ostracodes from North American Atlantic basins. The only information we have is contained in the following references: (1) Marine Upper Jurassic: Swain (1946) and Swartz and Swain (1946) (Louisiana and Arkansas), Swain (1952), Swain and Brown (1972) (North Carolina), and Swain and Anderson (in press) (North Louisiana). To complete the list, one should add Oertli (1972) on deep-sea offshore faunas near the Bahamas and Ascoli $(1976,1981)$ and Jansa et al. (1980) on Scotian Shelf microfaunas. (2) Marine lowest Cretaceous: Swain (1952, 1981, 1982); Swain and Brown (1972) (Atlantic Coastal Plain).

Seven species can be distinguished in my material. Unfortunately, their state of preservation is too poor to allow precise identification.

Asciocythere sp. This is the most frequent species and is present in all three samples. The length of the adults ranges from 0.052 to $0.055 \mathrm{~cm}$. It resembles Paraschuleridea twifordensis Swain and Brown, 1972, from "Unit H" (Neocomian-Aptian) of the Atlantic coastal region, but has a more rounded ventral margin. Asciocythere rotunda (Vanderpool, 1928). This is illustrated well by Swain (1952)

\footnotetext{
${ }^{1}$ Buffler, R. T., Schlager, W., et al., Init. Repts. DSDP, 77: Washington (U.S. Govt. Printing Office).
}

with "Trinity(?) and pre-Trinity(?)" material from Hatteras Light well 1 (North Carolina), and has some resemblance to the species in Section 537-11-1; it is, as the name indicates, rounded and has the line of maximum height situated halfway along its length. Asciocythere(?) cf. A. amygdaloides (Cornuel), from Hatteras Light well 1 (North Carolina), bears a closer resemblance to the species in my samples, but is less elongated. The specimens from Section 537-11-1 are also similar to Galliaecytheridea postrotunda Oertli, 1957, sensu Ascoli, 1976 (and Jansa et al., 1980); but the latter has its posterior extremity situated slightly above the ventral line.

Eocytheropteron(?) sp. This is present in all samples. This species is similar in outline to the "Trinity(?) and pre-Trinity(?)" species $C y$ theropteron (Eocytheropteron) tumoides Swain, 1952, which is, however, much taller $(0.088 \mathrm{~cm}$, against $0.047-0.048 \mathrm{~cm})$ and is ornamented ("pseudoreticulate pattern").

Cytherelloidea sp. (length of our specimens: $0.053-0.066 \mathrm{~cm}$ ). This is present from 0 to $10 \mathrm{~cm}$ in Section 537-11-1. The state of preservation is too poor to allow a specific determination of the arrangement of the surface ribs; it is possible merely to recognize that they are-or were-present. The species is remarkable because it is relatively elongate, compared with other specimens of the genus $C y$ therelloidea of a similar age.

Paracypris sp. (length 0.061-0.062 cm; Section 537-11-1, 0-4 and 134 $137 \mathrm{~cm}$ ). My specimens may be cospecific with Paracypris sp. of Swain (1952), which occurs in "Units G and H" of the Middle Atlantic states (Neocomian to lower Albian?). But Swain's species is $20 \%$ longer. My specimens also resemble Paracypris popei Swain and Anderson (in press) from the Upper Jurassic of northern Louisiana, but the latter is more pointed at the posterior. Paracypris specimens, with a similar outline, are also very frequent in the lowest Cretaceous of North Africa.

Schuleridea sp. (length $0.051 \mathrm{~cm}$; Section $537-11-1,0-10 \mathrm{~cm}$ ). This is quite similar to Schuleridea sp. 1 of Ascoli (1976) (Upper Jurassic of the Canadian Atlantic Shelf), but our species is apparently more elongated.

"Leptocythere" sp. (length $0.039-0.046 \mathrm{~cm}$; rare in all samples). This species receives its generic attribution from its outline, but there is little chance that with well-preserved specimens this name would be retained. It has a shape similar to Cushmanidea(?) sp. of Musacchio (1979), from the Hauterivian of Argentina, which is the same as gen. et sp. indet. of Musacchio (1978) (lower Barremian? of Argentina).

Centrocythere(?) sp. (length $0.039-0.051 \mathrm{~cm}$; present in all samples). This is another species which has an apparently overall reticulate surface, but where corrosion has left only traces. It bears a slight resemblance to Taxodiella sp. of Swain and Brown (1972) (Unit H, Atlantic coastal region), but the latter has a triangular posterior extremity and an almost winglike ventral overlap.

\section{AGE, PALEOGEOGRAPHY, AND PALEOECOLOGY}

No definite specific relationship with neighboring regions can be found, but I feel that this results from a poor state of preservation and the scarcity of published 

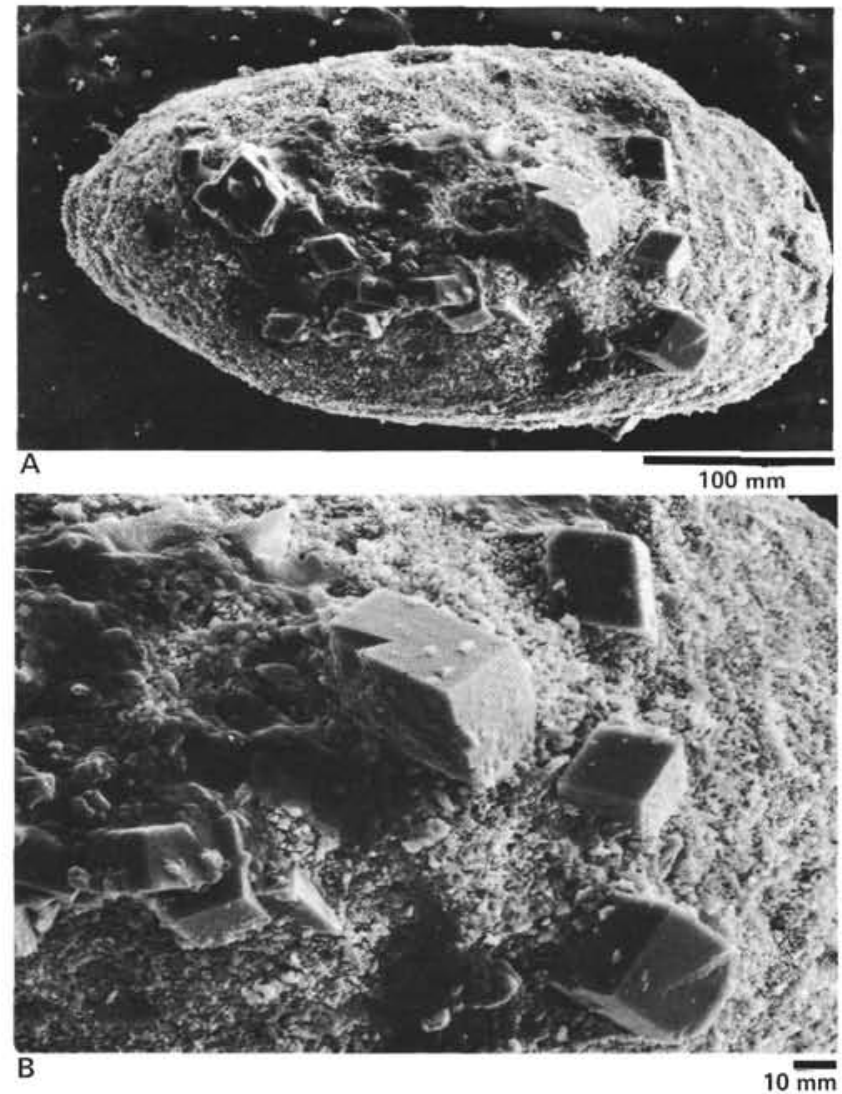

Figure 1. Conservation and crystallization (of a Eocytheropteron(?) sp. from Sample 537-11-1, 0-4 cm). A. Entire valve, showing calcite crystals of different sizes and the rugose surface. Magnified $\times 250$. B. Anterior part of the same valve, magnified $\times 1130$. It can clearly be seen that some crystals (for example, the large one above the center) simply lie on the surface (perhaps brought on $a$ posteriori), whereas others are deeply anchored. The surface consists of loosely arranged crystallites, which explains the "bad conservation" (Oertli, 1975). To the left, the outer "chitinous" layer is partly preserved, and it appears as though the growing crystals have risen and torn it. A study of Plates 1 and 2 shows that the surfaces of all the specimens are similarly preserved.

studies, rather than from a real absence of relationship. The observed association fits well in lowest Cretaceous shallow-water faunas of marine deposits observed elsewhere (North America and Europe); there is a sharp contrast between these and the deep-sea associations recovered near the Jurassic/Cretaceous boundary on Leg 11 (off Bahama Basin; Oertli, in press).

\section{REFERENCES}

Ascoli, P., 1976. Foraminiferal and ostracod biostratigraphy of the Mesozoic-Cenozoic, Scotian Shelf, Atlantic Canada. Marit. Sediments, Spec. Publ., 1:653-771.

1981. Foraminiferal-ostracod Late Jurassic biozonation of the Scotian Shelf. Geol. Surv. Ottawa, Open File 753.

Jansa, L. F., Remane, J., and Ascoli, P., 1980. Calpionellid and foraminiferal-ostracod biostratigraphy at the Jurassic-Cretaceous boundary, offshore eastern canada. Riv. Ital. Paleontol., 86:67-126.

Musacchio, E. A., 1978. Ostracodes del Cretacio inferior en el Grupo Mendoza, Cuenca del Neuquen, Argentina. Actas $7^{\circ}$ Congr. Geol. Argentino, 2:459-473.

1979. Datos paleobiogeograficos de algunas asociaciones de foraminiferos, ostracodos y carofitas del Jurasico medio y el Cretacico inferior de Argentina. Ameghiniana, 16:247-271.

Oertli, H. J,. 1957. Ostracodes du Jurassique supérieur du Bassin de Paris. Rev. Inst. Fr. Pet., 12:647-695.

1972. Jurassic ostracodes of DSDP Leg 11 (Sites 100 and 105)-preliminary account. In Hollister, C. D., Ewing, J. I., et al., Init. Repts. DSDP, 11: Washington (U.S. Govt. Printing Office), 645-657.

1975. The conservation of ostracode tests. Observations made under the scanning electron microscope. In Swain, F. M. (Ed.), Biology and Paleobiology of Ostracoda. Am. Paleontol. Bull. Spec. Publ., 65:549-575.

1983. Jurassic Ostracoda of DSDP Leg 76, Hole 534A (Blake Bahama Basin). In Sheridan, R. E., Gradstein, F. M., et al., Init. Repts. DSDP, 76: Washington (U.S. Govt. Printing Office), 581-584.

Swain, F. M., 1946. Upper Jurassic Ostracoda from the Cotton Valley Group in N Louisiana; the genus Hutsonia. J. Paleontol., 20: 119-129.

1949. Upper Jurassic of northeastern Texas. Am. Assoc. Petrol. Geol. Bull., 33:1206-1250.

1952. Ostracoda from wells in North Carolina. Part 2. Ostracoda. U.S. Geol. Surv. Prof. Paper 234-B, pp. 59-93.

1981. Mesozoic Ostracoda in several COST Atlantic wells. In Neale, J. W., and Brasier, M. D. (Eds.), Microfossils from Recent and Fossil Shelf Seas: Chichester (Ellis Horwood), pp. 90-112. , 1982. Marine and brackish water Cretaceous Ostracoda from wells in southern Florida. J. Micropalaeontol., 1:115-128.

Swain, F. M., and Anderson, E. G., in press. Upper Jurassic Ostracoda from northern Louisiana. La. Geol. Surv.

Swain, F. M., and Brown, P. M., 1972. Lower Cretaceous, Jurassic(?), and Triassic Ostracoda from the Atlantic coastal region. U.S. Geol. Surv. Prof. Paper 795.

Swartz, F. M., and Swain, F. M., 1946. Ostracoda from the Upper Jurassic Cotton Valley Group of Louisiana and Arkansas. J. Paleontol., 20:362-373.

Vanderpool, H. C., 1928. Fossils from the Trinity Group (lower Comanchean). J. Paleontol., 2:95-107.

Date of Initial Receipt: January 12, 1983

Date of Acceptance: July 22, 1983 


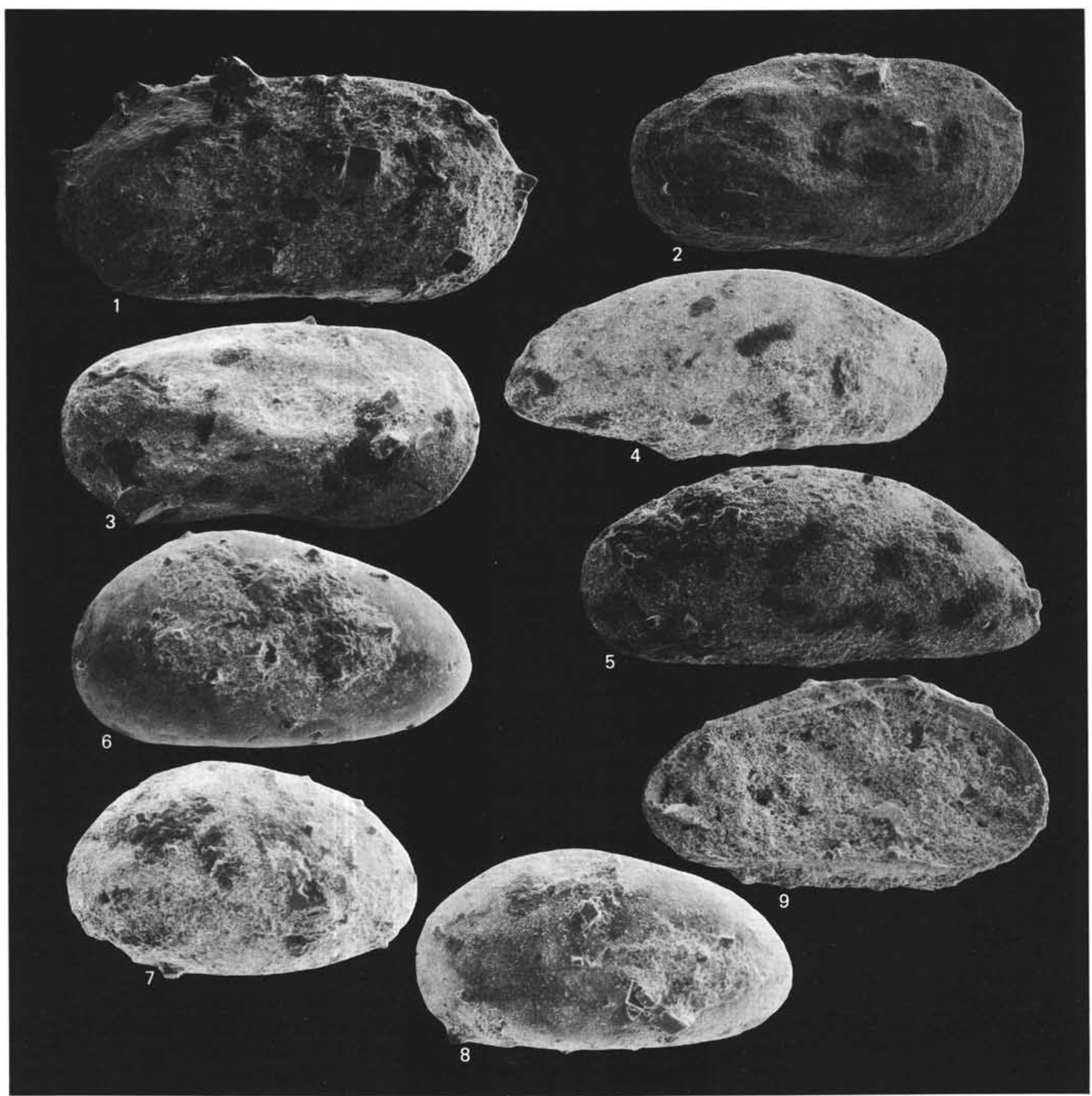

Plate 1. Lower Cretaceous ostracodes. (All specimens magnified approximately $\times 130$; all from Section 537-11-1). 1-3. Cytherelloidea sp. (left valve), $(1,2)$ sample interval $0-4 \mathrm{~cm}$, (3) sample interval 1-10 cm. 4, 5. Paracypris sp., (4) (left valve) sample interval 134-137 cm, (5) (right valve) sample interval 0-4 cm. 6-9. Asciocythere sp. (right valve), $(6,7)$ sample interval $0-4 \mathrm{~cm}$, (8) sample interval $1-10 \mathrm{~cm}$, (9) sample interval $0-4 \mathrm{~cm}$ (internal view). 


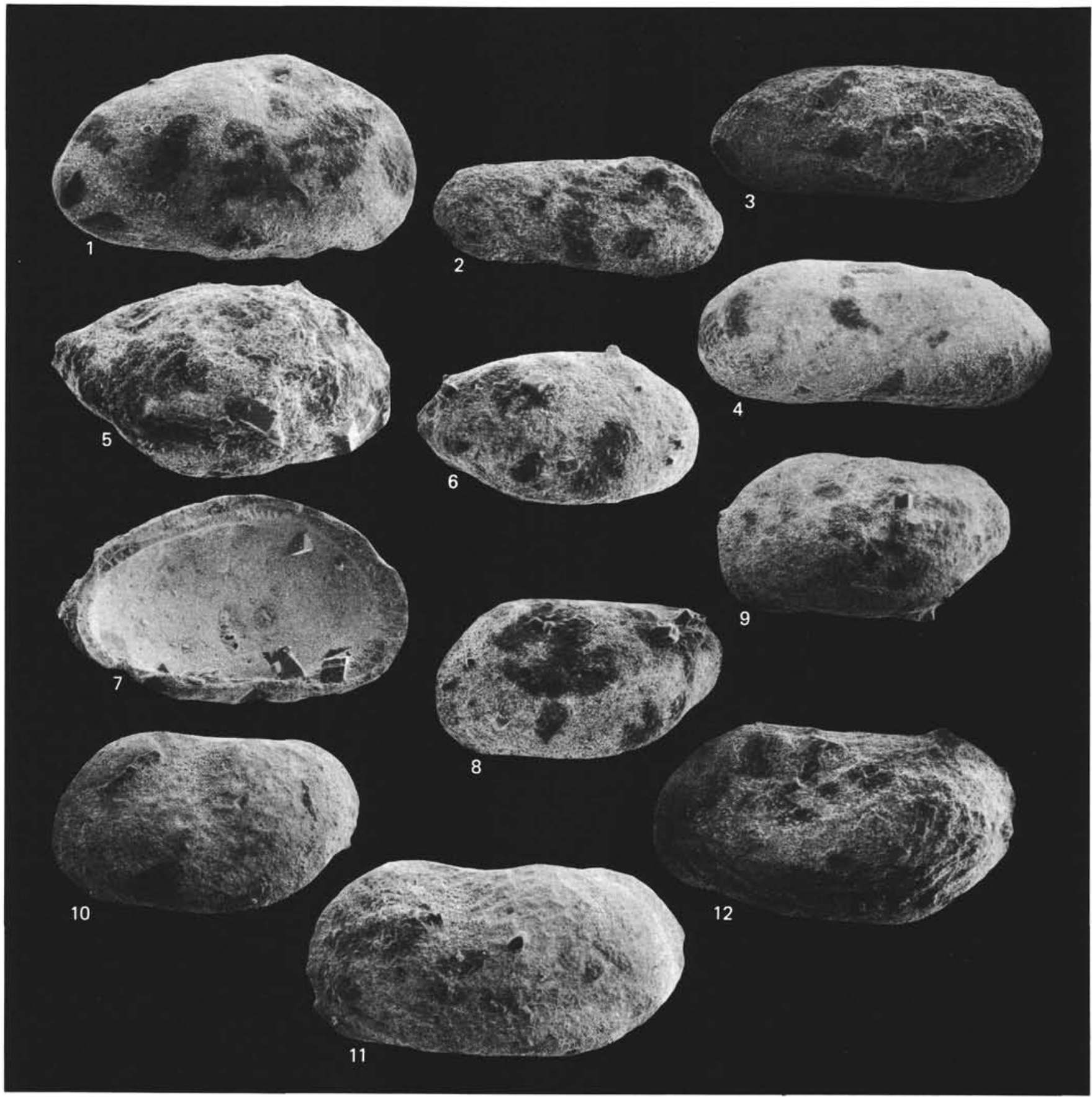

Plate 2. Lower Cretaceous ostracodes. (All specimens magnified approximately $\times 130$; all from Section 537-11-1). 1. Schuleridea sp. (right valve), sample interval 0-4 cm. 2-4. "Leptocythere" sp. (2) (right valve) sample interval 1-10 cm, (3, 4) sample interval 134-137 cm (3, right valve; 4, left valve). 5-7. Eocytheropteron(?) sp., $(5,6)$ (right valve) sample interval 0-4 cm (6, larval stage; 7 , internal view, left valve, sample interval 1-10 cm). 8-12. Centrocythere(?) sp. (left valve), (8) sample interval 1-10 cm, $(9,11)$ sample interval $0-4 \mathrm{~cm},(10,12)$ sample interval $134-137 \mathrm{~cm}$. 